\title{
PROJECT SCOPE MANAGEMENT PROCESS
}

\author{
Yana Derenskaya ${ }^{1}$ \\ National University of Pharmacy, Ukraine
}

\begin{abstract}
The purpose of the article is to define the essence of project scope management process, its components, as well as to develop an algorithm of project scope management in terms of pharmaceutical production. Methodology. To carry out the study, available information sources on standards of project management in whole and elements of project scope management in particular are analysed. Methods of system and structural analysis, logical generalization are used to study the totality of subprocesses of project scope management, input and output documents, and to provide each of them. Methods of network planning are used to construct a precedence diagram of project scope management process. Results of the research showed that components of the project scope management are managing the scope of the project product and managing the content of project work. It is the second component is investigated in the presented work as a subject of research. Accordingly, it is defined that project scope management process is to substantiate and bring to the realization the necessary amount of work that ensures the successful implementation of the project (achievement of its goal and objectives of individual project participants). It is also determined that the process of managing the project scope takes into account the planning, definition of the project scope, creation of the structure of project work, confirmation of the scope and management of the project scope. Participants of these subprocesses are: customer, investor, and other project participants - external organizations (contractors of the project); project review committee; project manager and project team. It is revealed that the key element of planning the project scope is the formation of the structure of design work, the justification of the number of works, and the sequence of their implementation. It is recommended to use the following sequence of stages for creating the structure of project work: analysis of results of planning the project scope; study of templates of project works' structures, recommendations for the formation of levels of structure; decomposition of the totality of project work; creating a dictionary of the project work structure; updating the description of the project scope and the project scope management plan. Practical importance. In order to improve the management of the scope of projects in the pharmacy, the components of subprocesses, participants, input and output documents are investigated and the algorithm for managing the project scope is built. It is determined that the starting elements of project scope management are the justification of the initial data, i.e. the project purpose, impacts of the environment and the internal potential of the enterprise in relation to the project implementation (assets of the organizational process). It is recommended to create a structure of project work starting from the analytical research existing at the enterprise or recommended by standards and guidelines on project management approaches to building a hierarchical structure of works, templates of project work structures. It is noted that the created structure of project work should be audited by participants of the project office. According to the results of planning the sequence and duration of operations for managing the scope of works, a precedence diagram of the investigated process is constructed. Value/originality. The developed recommendations regarding the consistency and structure of subprocesses and operations of the project scope management will allow the enterprise to significantly save time for planning the scope of subsequent projects, using the database created in previous periods, statistics on the implementation of the described operations.
\end{abstract}

Key words: project, project management, scope, project scope, project charter, work breakdown structure, project scope management.

JEL Classification: M11, L20, O21, O22

Corresponding author:

${ }^{1}$ Department of Management and Economy of Enterprises, National University of Pharmacy.

E-mail:y.derenskaya@gmail.com 


\section{Introduction}

The need to keep pace with development in order to confront competitors leads to the need for a modern pharmaceutical company to introduce new approaches to management. Intensification of activity in the development of new drugs, reconstruction, modernization of production, the search for new markets leads to the urgency of the application of methods and tools of project management. Accordingly, the start of the implementation of any project is related to the definition of its essence, planning the project scope.

Project scope management is related to performing processes that identify, plan, control the execution of the required amount of project work. In fact, scope management is a justification of the required amount of project work to ensure successful completion of the planned project. On the one hand, an insufficient amount of work can lead to the complexity of managing them, loss of management efficiency. On the other hand, too much detail requires large amounts of money and time to plan each work and monitor its execution. Therefore, project scope management determines the number and amount of project work necessary and sufficient for the successful implementation of project works.

The purpose of the article is to define the essence of the project scope management process, its components, as well as to develop an algorithm of project scope management in terms of pharmaceutical production.

To carry out the study, available information sources on standards of project management in whole and elements of project scope management in particular are analysed. Methods of the system and structural analysis, logical generalization are used to study the totality of subprocesses of project scope management, input and output documents, and to provide each of them. Methods of network planning are used to construct a schedule for project scope management.

\section{The essence of project scope management}

In project management, the term "scope" takes into account three components: product content, the content of works, project content (Fig. 1). According to the Guide to the Project Management Body of Knowledge (PMBOK ${ }^{\circledast}$ Guide, 2008), the term "scope" refers to the content of the product or the content of the project as a whole.

In the paper (Mazur, Shapiro, Ol'derogge, Polkovnikov, 2009), the project scope is considered as the content of works, for the effective management of which it is necessary to determine: the work to be performed; sequence of works; work duration; need for resources, and cost of work. S.H. Moroz and A.S. Nemchenko consider the content of works as "actions, descriptions of works to be performed, and resources to be secured” (Moroz, Nemchenko, 2017). ISO 21500 (ISO 21500:2012, 2012) defines scope as the processes necessary for identifying and defining works and results, as well as only the required work and results.

In terms of ISO 21500 (ISO 21500:2012, 2012), the project scope management takes into account the definition of content, the design of the project work, the definition of the composition of works, content

Project content management - processes of determining, justifying, and controlling the implementation of the required amount of project work that ensure the successful implementation of the project and the creation of a project product in accordance with the planned parameters (customer requirements)

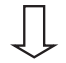

Project scope - works to be performed to get a product, service or result with planned features and functions

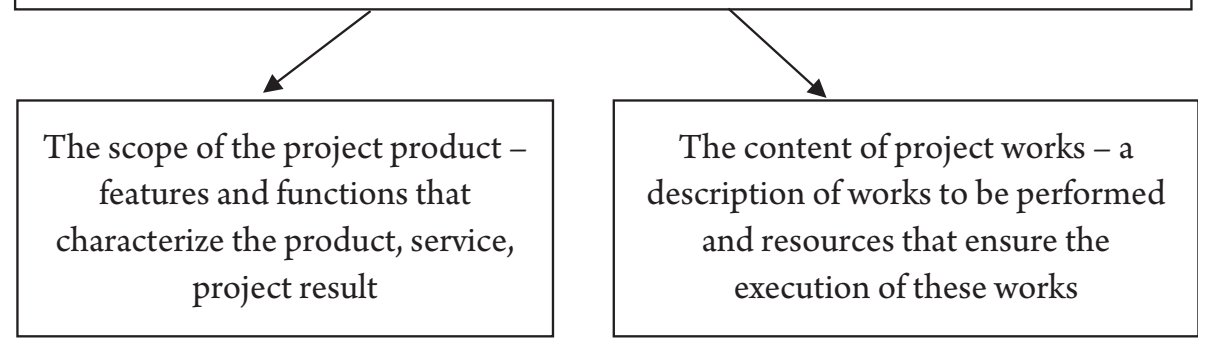

Fig. 1. Components of project scope management 
control. The purpose of the definition of the project scope is to identify the essence of the project scope, its purpose, results, requirements, and limits by analysing the final state of the project. Determining the content of the project shows the contribution of the project to the implementation of strategic objectives of the enterprise. A detailed description of the project scope is the basis of all project decisions, a base that links the importance of the project and the benefits that should be gained as a result of a successful project implementation. The main inputs for the process of defining the project scope for ISO 21500 (ISO 21500:2012, 2012) are the project charter and approved changes, and outputs are a description of the scope and requirements.

The purpose of creating a project works' structure is to create a presentation tool for a set of works in the form of a hierarchy of works that must be performed to achieve the purpose of the project. The structure of project works is the basis for splitting the project into more detailed levels and works that are easier to manage (to plan, control, etc.). The structure of design work can be formed on various grounds -phases, main results, functional areas, geographical location. Each subsequent level of structure takes into account a more detailed description of project works (detail may also include results, organizational aspects, risks, accounting of costs, resources, etc.). According to ISO 21500 (ISO 21500:2012, 2012), the main inputs of the process of creating a project work structure are project plans, requirements, approved changes, and outputs a hierarchical structure of work, a dictionary of the project work structure.

Definition of works is the process of identifying, defining, and documenting all operations that must be planned and implemented to achieve the purpose of the project. In addition, the definition of works may also include processes for identifying, defining, and documenting works that must be implemented at the lowest level of the project work structure. It is from this level that the definition of the work begins, that is, more detailed components form the basis for planning, implementation, control, and further closure of the project. Inputs of the process of determining the work include the hierarchical structure of works, its vocabulary, project plans, approved changes, and outputs - a list of works.

Scope control consists in determining its current status, comparing the current status of the scope with the approved base plan, detecting deviations, forecasting scope as of the project completion date, and implementing relevant changes requests in order to prevent the negative effects of changing the project scope. At the same time, the purpose of scope management is to enhance the positive and mitigate the negative consequences for the project, which arise due to changes in the scope. The process of scope control also involves identifying and managing factors that can change the scope of a project. From this perspective, scope control is considered in conjunction with the control of change. Scope control is also used to manage actual changes, as uncontrolled changes cause the scope to be offset. The main inputs of the content control process are data on the implementation of the project, a description of the project scope, project work structure, and a list of works, and outputs - requests for changes.

According to S. H. Moroz and A. S. Nemchenko, "management of the scope of the organization's work is a system of strategic integrated approaches to the effective functioning of the organization and its management system, which are aimed at achieving the mission and goals of the organization, provide an opportunity for effective operation of the organization and the effective work of its employees" (Moroz, Nemchenko, 2017).

In our view, processes of managing the scope of works are highlighted in more detail by the Guide to the Project Management Body of Knowledge $\left(\mathrm{PMBOK}^{\circ}\right.$ Guide, 2008), which links processes of scope planning, scope definition, project design, scope validation, scope management.

\section{Project scope management processes}

The analytical study of existing approaches to the formation of a set of subprocesses of project scope management, as well as taking into account the adaptation of standards for project management, allowed developing a model of the process of project scope management in the conditions of pharmaceutical production (Derenskaya, 2012), which takes into account the implementation of five subprocesses. Participants of these subprocesses are: customer, investor, and other project participants - external organizations (contractors of the project); project review committee; project manager and project team. The encoding of each subprocess includes the code of the scope management (У3) process and the serial number of the subprocess itself. The process of project scope management is to substantiate and bring to the realization the necessary amount of work that ensures the successful implementation of the project (achieving its goal and objectives of individual project participants).

The first subprocess - "Project scope planning" - is the work on the selection of approaches, methodologies, procedures, data sources, and other factors (which affect the formation of the complexity of the project) in order to create a plan for managing the project scope.

Using the results of the first subprocess, the project team defines a list of specific requirements for project works in terms of requirements of project participants, norms, restrictions. Results of the subprocess include: clearly defined goals of the project, defined project scope, its boundaries, requirements and results, performance criteria, constraints, preliminary schedule, and project estimates. 
The next subprocess ("Creating a project work structure") forms a decomposition of project work, taking into account a certain approach to grouping them. Structuring works can determine their interdependence, which is a prerequisite for the construction of the schedule and calendar plans for the project. In addition to the structure of the project work, the result of the subprocess is the WBS dictionary created, which allows unambiguous interpretation of the project terms by all project participants.

According to the results of the analytical study of project management standards, it is recommended to use the following sequence of stages of creating the structure of project work:

1. Analysis of results of project scope planning (assets of the organizational process, environmental factors, elements of the project scope management plan, charter, and description of the project scope).

2. Investigation of templates of project structures, recommendations for the formation of levels of structure.

3. Decomposition of the totality of project works.

3.1. Identification of inputs and outputs (input data and results) for each stage of the project, formation of the first level of the project work structure.

3.2. Structuring of the stages, grouping of blocks of works.

3.3. Detailing the blocks of work by the results of breaking the upper levels into elements.

3.4. Checking the necessity of the work done on the work packages and the adequacy of the degree of decomposition of works.

3.5. Identification of elements of the structure of project work (development and assignment of code to each element of the structure).

4. Creation of a dictionary of project work structure, which allows unambiguous interpretation of project terms by all project participants.

5. Updating the description of the project scope and the project scope management plan.

Formation of templates of project work structures allows the project team to save time on project planning as a result of applying corrective actions or updating similar structures that were worked out in the process of implementation of previous projects of the enterprise.

Confirmation of the project scope is a formal acceptance by the project participants of the WBS created. The subprocess takes into account the verification of the project scope by verifying the readiness of the participants to complete the project work and document the appropriate parameters.

If necessary, the corresponding change in the project scope (specific work) is revealed, documented, and substantiated, which requires a certain replanning of the project scope and all its parameters. Project scope management is to ensure that the change of the identified changes at all stages and procedures for project change management is carried out. This subprocess also manages the current changes in the project work parameters, integrating the project scope management process with the management of terms, cost, quality of the project, and other processes. The results of this subprocess are the updated description of the project scope, project work structure, project scope management plan.

In terms of pharmaceutical production, it is recommended to use the algorithm shown in Fig. 2 to control the scope of executable projects. The starting elements for managing the project scope are the justification of the initial data, that is, the purpose of the project, impacts of the environment and the internal capacity of the enterprise in relation to the project implementation (availability of knowledge base, experience of the project activity - assets of the organizational process). The established Charter, a preliminary description of the scope, and the project management plan are subject to obligatory examination by a project review committee, a project office. Clarifying the needs and expectations of project participants helps to formulate their requirements for results and form a description of the project scope.

The next stage of the project scope management algorithm - the creation of a project work structure begins with an analytical study of existing at the enterprise or recommended by standards and guidelines for project management approaches to building a hierarchical structure of work, templates of project work structures. The analysis conducted determines the list of works to be done in order to achieve the results previously determined by the project.

Decomposition (distribution by levels and corresponding grouping) of project works allows forming a structure of project works, the description of which is carried out with the help of a dictionary of the structure of project work. Simultaneously with the creation of the structure of project work, changes are made to the planned project documents.

The created structure of project work is subject to audit by project office participants, who, in case of discrepancies or insufficient disclosure of levels or number of works, may formulate relevant requests for changes in the scope of works. In case of necessity of making changes, they are substantiated by calculations of economic indicators (time, costs, change of project efficiency, etc.). Approved by the project review committee and the project office, changes are implemented by adjusting the project plans.

The updated scope of the project, description of the project scope, project work structure, the vocabulary of the project work, scope management plan, project management plan are subject to approval by the project review committee.

Characteristics of operations proposed for managing the project scope is shown in Table 1. Each operation is 


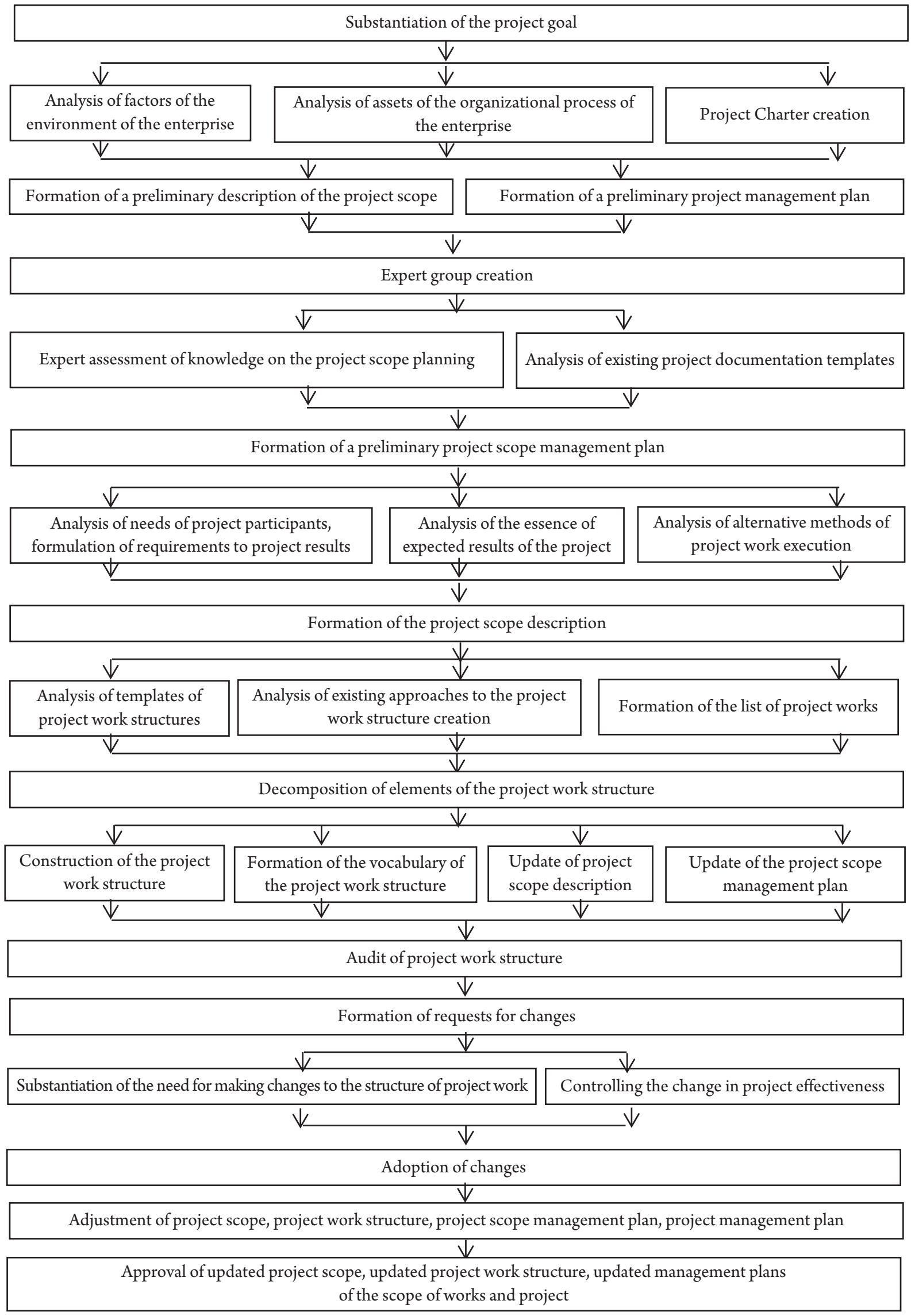

Fig. 2. Project scope management algorithm 
coded as follows: $\mathrm{Y} 3$ - the name of the process - project scope management; the second digit - subprocess number ( 1 - scope planning, 2 - definition of the project scope, 3 - creation of the structure of project work, 4 - confirmation of the project scope, 5 scope management); the third digit of the code is the serial number of the operation of the corresponding subprocess of the project scope management. The duration of operations is determined by the example of managing the scope of a project of one of the Ukrainian pharmaceutical companies.

Based on the results of planning the sequence and duration of operations for managing the scope of works in the absence of an accumulated knowledge base in the enterprise, a precedence diagram of the investigated process is built, which is shown in Fig. 3.

Thus, the critical path is formed by:

$\mathrm{Y} 3.1 .1 \rightarrow \mathrm{Y3} .1 .4 \rightarrow \mathrm{Y} 3.1 .6 \rightarrow \mathrm{Y} 3.1 .7 \rightarrow \mathrm{Y3} .1 .8 \rightarrow \mathrm{Y} 3.1 .10 \rightarrow$ $\mathrm{y} 3.2 .1 \rightarrow \rightarrow \mathrm{Y} 3.2 .2 \rightarrow \mathrm{Y} 3.2 .5 \rightarrow \mathrm{Y} 3.3 .3 \rightarrow \mathrm{Y} 3.3 .4 \rightarrow \mathrm{Y} 3.3 .5 \rightarrow$
Y3.4.1 $\rightarrow$ Y3.4.2 $\rightarrow$ Y3.5.1 $\rightarrow \rightarrow$ Y3.5.3 $\rightarrow$ Y3.5.6 $\rightarrow$ Y3.5.7 $\rightarrow$ Y3.5.8

According to the enterprise's forecasts, the duration of the scope management process in the absence of an accumulated knowledge base will be 70 days (that is, about 3.5 months).

\section{Conclusions}

According to the results of the research, the following conclusions can be drawn:

1. One of the processes of project management is the project scope management process, which takes into account the planning, definition of the project scope, creation of the structure of project works, confirmation of the scope, and project scope management.

2. In order to improve the management of the scope of projects in the pharmacy, the components of subprocesses, participants, input and output documents are studied, and the project scope management algorithm

Table 1

Characteristics of operations of the project scope management process

\begin{tabular}{|c|c|c|c|}
\hline Code & Name of operation & Previous operation & Duration, days \\
\hline У3.1.1 & Substantiation of the project goal & - & 1 \\
\hline y3.1.2 & Analysis of factors of the environment of the enterprise & У3.1.1 & 5 \\
\hline y3.1.3 & Analysis of assets of the organizational process of the enterprise & У3.1.1 & 4 \\
\hline У3.1.4 & Project Charter creation & У3.1.1 & 6 \\
\hline y3.1.5 & Formation of a preliminary description of the project scope & У3.1.2; У3.1.3; У3.1.4 & 4 \\
\hline У3.1.6 & Formation of a preliminary project management plan & У3.1.2; У3.1.3; У3.1.4 & 5 \\
\hline У3.1.7 & Expert group creation & У3.1.5; У3.1.6 & 3 \\
\hline У3.1.8 & Expert assessment of knowledge on the project scope planning & У3.1.7 & 5 \\
\hline У3.1.9 & Analysis of existing project documentation templates & У3.1.7 & 2 \\
\hline Y3.1.10 & Formation of a preliminary project scope management plan & У3.1.8; У3.1.9 & 3 \\
\hline У3.2.1 & Analysis of needs, requirements, and expectations of project participants & У3.1.10 & 3 \\
\hline У3.2.2 & Formulation of requirements of project participants to its results & У3.2.1 & 1 \\
\hline У3.2.3 & Analysis of the essence of expected results of the project & У3.1.10 & 2 \\
\hline У3.2.4 & Analysis of alternative methods of project work execution & У3.1.10 & 2 \\
\hline У3.2.5 & Formation of the project scope description & У3.2.2; У3.2.3; У3.2.4 & 4 \\
\hline y3.3.1 & Analysis of templates of project work structures & У3.2.5 & 2 \\
\hline У3.3.2 & Analysis of existing approaches to the project work structure creation & У3.2.5 & 1 \\
\hline У3.3.3 & Formation of the list of project works & У3.2.5 & 5 \\
\hline У3.3.4 & Decomposition of elements of the project work structure & У3.3.1; У3.3.2; У3.3.3 & 4 \\
\hline y3.3.5 & Construction of the project work structure & У3.3.4 & 3 \\
\hline У3.3.6 & Formation of the vocabulary of the project work structure & У3.3.4 & 2 \\
\hline y3.3.7 & Update of project scope description & У3.3.4 & 2 \\
\hline Y3.3.8 & Update of the project scope management plan & У3.3.4 & 2 \\
\hline Y3.4.1 & Audit of project work structure & У3.3.5; У3.3.6; У3.3.7; У3.3.8 & 4 \\
\hline y3.4.2 & Formation of requests for changes in the scope of project work & У3.4.1 & 2 \\
\hline Y3.5.1 & Substantiation of the need for making changes to the structure of project work & У3.4.2 & 5 \\
\hline y3.5.2 & Controlling the change in project effectiveness & y3.4.2 & 3 \\
\hline y3.5.3 & Adoption of changes to the project work structure & У3.5.1; У3.5.2 & 3 \\
\hline y3.5.4 & Project scope description adjustment & У3.5.3 & 2 \\
\hline y3.5.5 & Project work structure review & У3.5.3 & 3 \\
\hline y3.5.6 & Project scope management plan adjustment & У3.5.3 & 5 \\
\hline y3.5.7 & Project management plan adjustment & У3.5.4; У3.5.5; У3.5.6 & 7 \\
\hline У3.5.8 & $\begin{array}{l}\text { Approval of updated documents (project scope description, project work } \\
\text { structure, project scope management plan, project management plan) }\end{array}$ & У3.5.7 & 1 \\
\hline
\end{tabular}


is constructed. It is revealed that the key element of the project scope planning is the formation of the structure of project work, the justification of the number of works, and the sequence of their implementation.

3. As a result of the planning of the sequence and duration of operations for managing the scope of works, a precedence diagram of the investigated process is constructed. The developed recommendations regarding the consistency and structure of subprocesses and operations of project scope management will allow the enterprise to significantly save the time of planning the scope of subsequent projects, using the database created in previous periods, statistics on the implementation of the described operations.
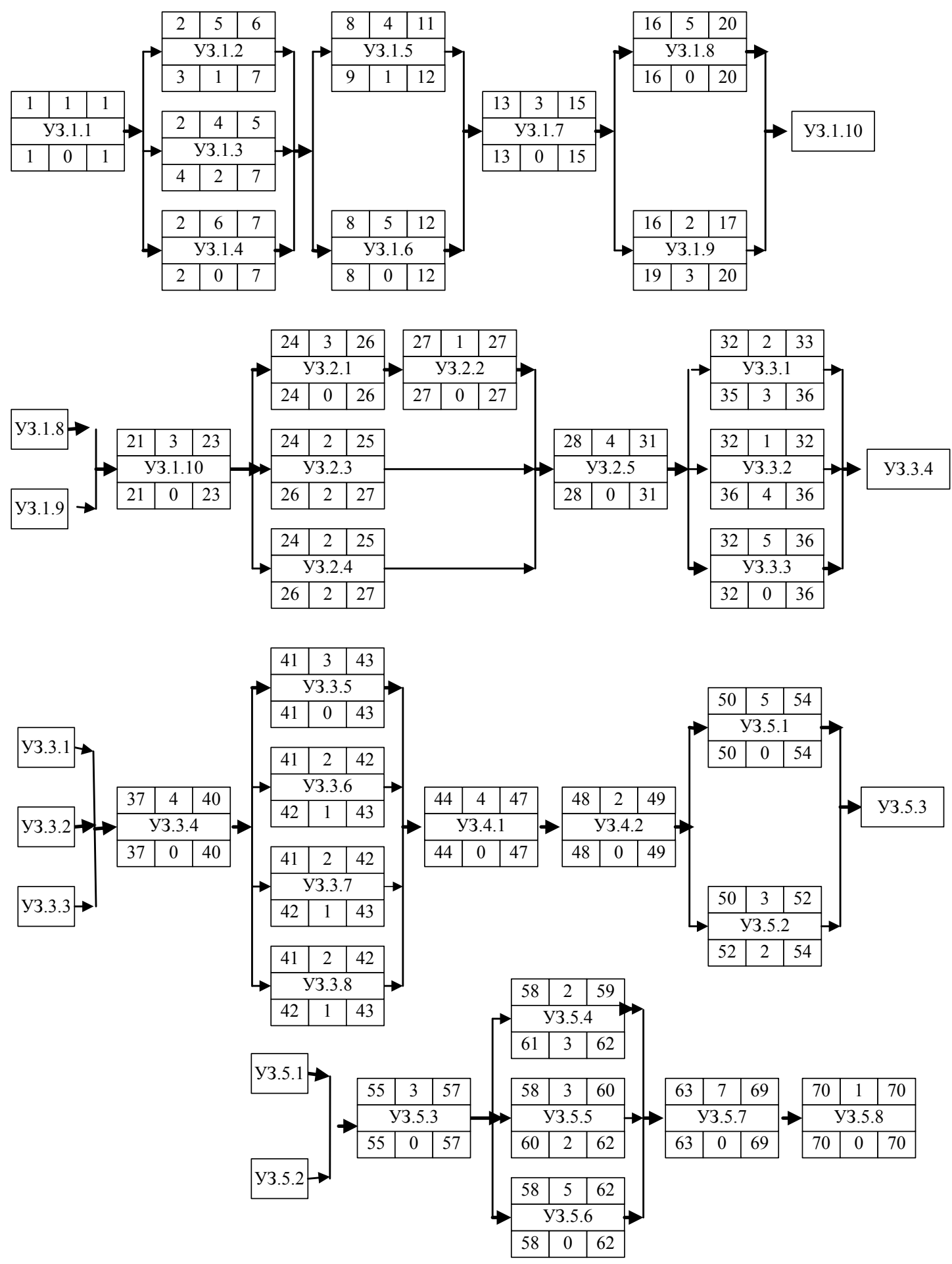

Fig. 3. Precedence diagram of the project scope management process 


\section{References:}

Project Management Institute (2008). A Guide to the Project Management Body of Knowledge (PMBOK Guide). Newtown Square, Pennsylvania, USA: Project Management Institute.

Derenskaya Y. N. (2012). Skladovi protsesu upravlinnya zmistom proektu [Components of the project scope management process]. Proceedings of the Reformuvannya ta rozvytok nauky: suchasni vyklyky (Ukraine, Kyiv, February 20, 2012), Kyiv: Tsentr naukovyh publikatsiy, pp. 39-41.

ISO 21500:2012. (2012). Guidance on Project Management. Retrieved from: www.mosaicprojects.com.au/PDF/ ISO_21500_Communique_No1.pdf(accessed 5 June 2014).

Mazur I. I., Shapiro, V. D., Ol`` derogge N. H., Polkovnikov A. V. (2009). Upravlenie proektami [Project management]. Moscow: Omega-L. (in Russian)

Moroz S. H., Nemchenko A. S. (2017). Upravlinnya zmistom robit [Project scope management]. Kharkiv: NPhaU. (in Ukrainian)

Petrenko N. O., Kustrich L. O., Homenyuk M. O. (2015). Upravlinnya proektamy [Project management]. Kyiv: Tsentr uchbovoyi literatury. (in Ukrainian)

Polkovnikov A. V., Dubovik M. F. (2011). Upravlenie proektami [Project management]. Moscow: Eksmo. (in Russian)

Posylkina O. V., Derenskaya Y. N., Kostyuk G. V. (2010). Upravlinnya proektamy u farmatsevtychnomu vyrobnytsvi [Project management in pharmaceutical industry]. Kharkiv: NPhaU. (in Ukrainian) 